\title{
The political ecology of participatory conservation: institutions and discourse
}

\author{
R. Patrick Bixler ${ }^{\text {a, } 1}$ \\ Jampel Dell'Angelo b, c \\ Orleans Mfune ${ }^{d}$ \\ Hassan Roba ${ }^{\text {e }}$ \\ a Texas A\&M University, USA \\ ${ }^{\mathrm{b}}$ University of Maryland, USA \\ c Indiana University, USA \\ ${ }^{\mathrm{d}}$ University of Zambia, Zambia \\ e National Museums of Kenya, Kenya
}

\begin{abstract}
Increasingly, natural resource conservation programs refer to participation and local community involvement as one of the necessary prerequisites for sustainable resource management. In frameworks of adaptive comanagement, the theory of participatory conservation plays a central role in the democratization of decisionmaking authority and equitable distribution of benefits and burdens. We observe, however, that the institutions of state, society, and economy shape the implementation and application of participation in significant ways across contexts. This paper examines the political ecology of participation by comparing and contrasting discourse and practice in four developed and developing contexts. The cases drawn from Central Asia, Africa, and North America illustrate that institutional dynamics and discourse shape outcomes. While these results are not necessarily surprising, they raise questions about the linkages between participatory conservation theory, policy and programmatic efforts of implementation to achieve tangible local livelihood and conservation outcomes. Participation must be understood in the broader political economy of conservation in which local projects unfold, and we suggest that theories of participatory governance need to be less generalized and more situated within contours of place-based institutional and environmental histories. Through this analysis we illustrate the dialectical process of conservation in that the very institutions that participation is intended to build create resistance, as state control once did. Conservation theory and theories of participatory governance must consider these dynamics if we are to move conservation forward in a way that authentically incorporates local level livelihood concerns.
\end{abstract}

Keywords: participatory governance, political ecology, community-based conservation, environmental governance, discourse

\section{Résumé}

De plus en plus, les programmes de conservation des ressources naturelles disent que la participation et l'implication de la communauté locale sont des préalables nécessaires à une gestion durable des ressources. Dans les cadres de la co-gestion adaptative, la théorie de la conservation participative joue un rôle central dans la démocratisation de l'autorité sur la prise de décision, et de la répartition équitable des bénéfices. Nous observons, cependant, que les institutions de l'État, la société et l'économie façonnent la mise en œuvre et l'application de la participation d'une manière significative à travers les contextes. Cet article examine l'écologie politique de la participation dans quatre contextes développés et en développement, et il comparant et contrastant ses discours et des pratiques. Les cas sont tirées de l'Asie centrale, en Afrique et en Amérique du

\footnotetext{
${ }^{1}$ Dr. R. Patrick Bixler, Research Scientist, Institute of Renewable Natural Resources, Texas A\&M University, 1500 Research Parkway A110, 2260 TAMU, College Station, TX 77843-2260, USA. Email: r.patrick.bixer "at" gmail.com. We thank the Thor Heyerdahl Summer School in Environmental Governance for catalyzing this collaboration. We would also like to thank JPE editor Dr. Casey Walsh and two anonymous reviewers for their helpful guidance.
} 
Nord et montrent que les dynamiques institutionnelles et les discours sont les facteurs plus important de façonner les résultats des projets. Bien que ce ne sont pas nécessairement surprenant, les études de cas soulèvent des questions sur les liens entre la théorie de la conservation participative, la politique et les efforts de mise en œuvre programmatiques. Les projets cherchent à atteindre des résultats tangibles sur «livelihood outcomes» et le conservation. Mais l'utilisation de la participation doit être comprise dans l'économie politique plus large, dans lequel les projets locaux de conservation se déroulent. Nous suggérons que les théories de la gouvernance participative ont besoin d'être moins généralisée et plus situés dans les contours des histoires territorialisées des institutions et l'environnement. Nous illustrons le processus dialectique de conservation, où les institutions mêmes que la participation est destiné à construire créer une résistance, tout comme le contrôle de l'État a fait autrefois. La théorie de la conservation, et les théories de la gouvernance participative, doivent tenir compte de ces dynamiques si nous voulons aller de l'avant dans la conservation d'une manière qui intègre authentiquement les préoccupations de «livelihoods» au niveau local.

Mots-clés: la gouvernance participative, l'écologie politique, conservation à la base communautaire, la gouvernance de l'environnement, le discours

\section{Resumen}

Cada vez con más frecuencia, los programas de conservación de recursos naturales establecen la participación comunitaria como elemento necesario de la sustentabilidad. En el marco conceptual del "co-manejo adaptivo", la idea de conservación participativa juega un papel central en la democratización de la autoridad para la toma de decisiones y la distribución equitativa de beneficios y responsabilidades. Sin embargo, observamos que las instituciones del estado, sociedad y economía dan forma a la manera en que las ideas sobre participación están implementadas en una variedad de contextos. Este artículo examina a la ecología política de la participación, comparando su discurso y practica en cuatro lugares, tanto desarrollados como en vías de desarrollo. Estudios de caso en la Asia Central, África y América del Norte ilustran como estas dinámicas y discursos institucionales condicionan sus resultados. Aunque no sorprende, esto llama la atención a los vínculos entre la teoría de conservación participativa, la política pública, y los esfuerzos para lograr resultados concretos en el ámbito de economías locales y conservación. Sugerimos que teorías de gobernanza participativa deberían ser menos generales y mejor ubicadas dentro de historias institucionales y ambientales locales. De esta manera señalamos el carácter dialéctico del proceso de conservación, según lo cual las mismas instituciones que la participación construye crean resistencias, similar a lo que paso anteriormente al control ejercido por el estado. La teoría de la conservación tiene que considerar estas dinámicas si espera realmente lograr las prioridades locales de sustento socioeconómico.

Palabras Clave: gobernanza participativa, ecología política, conservacion comunitaria, gobernanza ambiental, discurso

\section{Introduction}

Participation has gained cache and traction in coupled development-conservation programs and projects all across the world (Cornwall and Brock 2005). Collaborative management approaches that promote joint conservation and development strategies between land management authorities and local peoples have increased substantially in agricultural, forestry, and rangeland systems since the 1980s. This has been mapped out in the historical and conceptual genealogy of conservation discourse and practice (Vaccaro et al. 2013). While the notion and theory of 'participation' is rather simple, its implementation has had broad and varying results. Different actors (including NGOs, governments, and international agencies) with different agendas often interpret the notion of participation differently, which influences the way participation is practiced. The practice of participatory governance is subject to the broader contours of environmental and resource extraction interests and knowledges of the invested stakeholders of state and non-state actors. As argued by many critical scholars, participatory forms of nature conservation must be understood as political project in the context of a neoliberal accumulation regime (Khan and Lynch 2013). This paper examines the political ecology of participatory conservation by comparing and contrasting the discourse and practice in four contexts: Kenya, Zambia, the United States, and the People's Republic of China.

We discuss several factors - including existing institutions of power and authority, land tenure structures, the nature of poverty, and challenges of researcher access to concrete processes and outcomes - that present many challenges to such a cross-country analysis. Because of these challenges, multi-country critical 
comparisons are rare in the literature. Nonetheless, we argue that more cross-country and global north-south comparisons are needed as global discourses such as participation are applied indiscriminately across contexts.

\section{Participatory conservation, discourse, and institutions}

In the following, we will discuss the literature on participatory conservation, followed by a theoretical framework applied to the case studies. This framework is informed by political ecology and draws on the literature on discourse and institutions.

\section{Participation}

For most of the past century, natural resource conservation was characterized by centralized modes of environmental decision making that placed natural resources under the control of state bureaucracies and marginalized local actors who were often dependent on the same resources for survival (see Adisu and Croll 1994) or their livelihoods (Western and Wright 1994). This was the case in many parts of the world where common-pool resources were appropriated from local actors and designated as protected areas where human activities were excluded (Campbell 2000; Hulme and Murphree 1999; Siurua 2006; Sullivan and Homewood 2004). These exclusionary modes of environmental governance were often backed by 'scientific narratives' that represented natural resources as threatened by the activities of local actors in proximity to these resources (Forsyth 2003). In particular, equilibrium thinking in ecological theory was instrumental in forging a conservation approach that favored exclusive control of natural resources by state experts (Forsyth et al. 1998; Forsyth 2003; Gillson 2004; Hurley et al. 2002; Lankford and Beale 2002). This was in large part driven by the narrative of the Tragedy of the commons that represented local actor's exploitation of common-pool resources as 'tragic' (Hardin 1968). Although many authors have noted Hardin was describing a tragedy of 'open access' and not a tragedy of the 'commons', his paper was nonetheless influential in legitimizing the view that common-pool resources required the state or the market in order to avoid tragedy (see Bryant and Bailey 1997; Ostrom 1990; Sullivan and Homewood 2004). It served to reinforce the importance of the protected area approach to conservation, as well as encouraged policy reforms that sought to dissolve common property systems in favor of state and private property.

Over the past 30 years, however, a combination of factors have weakened the hegemony of conservation models based on centralized natural resource management. Many studies have demonstrated the failure of this approach to protect natural resources (Grimble and Laidlaw 2002; Hulme and Murphree 1999; Rinzin 2009) and studies from institutional theorists including Ostrom $(1990,1999)$ have offered mounting and indisputable evidence for the inherent capacity of local actors to act collectively in order to solve environmental problems (also Roe et al. 2009; Scherr 2000; Stringer 2009; Xu et al. 2008). In some parts of the world, local people challenged state power and forced it to yield ground, as Banerjee (2001) outlines for the tree-hugging movement in India, and the resistance movement against logging in Borneo. This period has also witnessed a major trend in natural resource management policy and practice, decentralization (Berkes 2010; Larson and Soto 2008). After clear failures of the state to manage natural resources to meet local needs, in the early 1990s community involvement and problem-solving at the lowest feasible level of organization (the subsidiary principle), became alternatives to top-down management of natural resources (Agrawal and Gibson 1999, 2001; Brosius et al. 1998; Ribot 2002; Scott 1998; Western and Wright 1994). In a variety of natural resource sectors, developed and developing countries have experimented with shifting natural resource governance responsibilities down from centralized governments to local institutions, thus enlivening the debate about the role of local participation in natural resource management.

These trends and movements have led to the 'enactment' of a new narrative, participatory conservation. Participation as a key dimension for natural resource management has been endorsed by the international environmental community at the Rio Conference in 1992, and gained legitimacy as a style of managing the environment when it was unveiled as one of the key principles of sustainable development. The 1990s saw a new conservation paradigm emerging, one presented as offering win-win solutions to a host of environmental challenges such as deforestation, watershed degradation and depletion of rangelands on the ground, where various actors are involved in defining the goals and means of natural resources conservation. Conservation 
theorists and development practitioners have advanced this discourse, one where participation is related to good governance in the form of transparent and accountable actors (Mery et al. 2005).

'Participation', as a central tenet, refers to the inclusion of those who are affected or who can affect a decision (Reed 2008; Ribot 2002). Many different typologies exist to delimit the type and kinds of participation, including the degree to which stakeholders are engaged, represented by a 'ladder of participation' (Arnstein 1969; Hobley 1996). One of the most widely adopted is Biggs (1989), who described the level of engagement as a relationship that can be "contractual", "consultative", "collaborative" and "collegiate." Lawrence (2006) built on this, proposing "transformative" participation as an alternative top rung of the ladder, and emphasizing the idea that empowerment should lead to the transformation of the communities who are involved. The hierarchical nature of this ladder metaphor implies higher rungs are preferred, but different levels of engagement are likely to be appropriate in different contexts.

Other participation typologies focus on the nature, rather than the degree, of engagement, where information dissemination to passive participants represents "communication", gathering information from participants is "consultation", and "participation" is conceptualized as a two-way flow of communication (Rowe and Frewer 2000). Other typologies distinguish between a participation that is pragmatic and/or normative. Habermas' communicative action theory (1984) suggests participation should be "fair", representing a full range of relevant stakeholders and equalizing power between participants. This conceptualizes participation as a means to an end, that delivers higher quality decisions.

Participation, however, is a very multi-faceted, normatively and ideologically loaded, and a complex term that looks different across social, economic, political, and ecological contexts. Elsewhere, participatory governance is discussed as leading to unjust and illegitimate exercise of power in ways that are tyrannical (Cooke and Kothari 2001). Participatory forms of natural resource management are often delimited to defined projects, have trouble influencing traditional hierarchical and bureaucratic governance structures, and require appropriate training, expertise, and experience to advance to implementation (Cooke and Kothari 2001).

While there is still much promise in the notion of participation, the outcomes of participatory conservation initiatives have not always met expectations (Blaikie 2006). In many instances, governments have been reluctant to devolve power to bodies that are accountable to, and representative of, local people and in other cases they have recentralized power through other means (Nelson 2010; Ribot et al. 2005). Whereas discourses of participation at the global level are appealing and relatively uniform, implementation at the national or local level has taken multiple forms and meanings (Blaikie 2006; Cornwall et al. 2005). 'Participation' is indeed such an imprecise and ambiguous concept that participatory resource management has often been used as a catch-it-all construct to cover many different resource management arrangements and to serve multiple interests (Sullivan and Homewood 2004). For instance, participatory development has offered a convenient way for the state to maintain existing power relationships and to ensure the silence of the poor (Botes and van Rensburg 2000). As Hobley (2006) presents, participation covers a broad spectrum of forms (Table 1). Participation lacks conceptual clarity, and serious concerns are raised in local contexts during the implementation from theory to practice. With so many resource management programs across the world touting participation, and by proxy legitimation, this article unpacks how participation is captured, particularized and contextualized in practice across our cases.

\section{Political ecology as an analytical framework}

Political ecology has gained ground in social-ecological research as a mode of analyzing societyenvironment relationships (Robbins 2004; Zimmerer 2006; Kepe et al. 2008; Bixler 2013). According to Simsik (2002), political ecology articulates the motivations, interests and actions of various actors vying for access to and control of resource management. Political ecology provides a useful theoretical framework as environmental issues become increasingly prominent in local struggles, national debates, and international efforts. Specifically, we identify with what Forsyth defines as 'critical political ecology', an approach that questions the neutral validity of scientific explanations in politically charged contexts such as the socioenvironmental field, but it does not negate the existence of a 'real world out there' (2003:11). Such an approach enables this research to focus on the way the discourses of participation are framed in various socio-cultural 
contexts and the role of power and social relations in determining the right to access and management of natural resources (Berkes 2004; Brown 2003).

\begin{tabular}{|c|c|}
\hline Typology & Characteristics of each type \\
\hline $\begin{array}{l}\text { Manipulative } \\
\text { participation }\end{array}$ & $\begin{array}{l}\text { Participation is a pretense (people's representatives on official boards but unelected } \\
\text { and have no power). }\end{array}$ \\
\hline $\begin{array}{l}\text { Passive } \\
\text { participation }\end{array}$ & People participate by being told what has been decided or what has happened \\
\hline $\begin{array}{l}\text { Participation by } \\
\text { consultation }\end{array}$ & People participate by being consulted or by answering questions \\
\hline $\begin{array}{l}\text { Participation for } \\
\text { material incentives }\end{array}$ & People participate by contributing material resources (e.g. they contribute labor) \\
\hline $\begin{array}{l}\text { Functional } \\
\text { participation }\end{array}$ & $\begin{array}{l}\text { Participation is seen by external agents as a means to achieve programme goals. In } \\
\text { this case, people are only co-opted to serve external objectives, while all major } \\
\text { decisions have already been made by external actors }\end{array}$ \\
\hline $\begin{array}{l}\text { Interactive } \\
\text { participation }\end{array}$ & $\begin{array}{l}\text { People participate in joint analysis, development of action plans, or formation or } \\
\text { strengthening of local institutions. Groups take control over local decisions and } \\
\text { determine use of available resources }\end{array}$ \\
\hline Self-mobilization & $\begin{array}{l}\text { People take initiatives independently to change systems and develop contacts with } \\
\text { external actors for resources and technical advice }\end{array}$ \\
\hline
\end{tabular}

Table 1: Typologies of participation: how people participate in natural resource conservation (Hobley 1996: 8).

By bringing attention to more broadly defined relations of power and difference in interactions among human groups and their biophysical environments (Gezon and Paulson 2005), political ecology provides a tool kit of concepts to look beyond the local community to explain resource use and power dynamics in everyday interactions and formal policy arenas and across multiple scales. We use political ecology to examine the factors that shape relations of power between different social groups the biophysical landscape, and global processes. By doing so, we challenge the prominent interpretations of participatory conservation. As Figure 1 illustrates, we are particularly interested in the interplay between discourse and institutions across levels of governance in producing participatory conservation across our case studies.

\section{Discourse}

There are many ways to conceptualize power in political ecology and elsewhere. For example, when discussing the human/society/nature nexus in co-management conservation, Khan (2013) discusses power in the context of the critical moment involving the actors and the event itself. We argue here that the broader discourse frames the power relations in that critical moment, by legitimizing and (de) legitimizing institutional arrangements (Hajer 1995). In assessing discourse, we largely draw on a Foucauldian discursive notion that focuses on the 'non-material' dimensions of power. Researchers utilizing such approaches tend to analyze the broader role of discourses in promoting certain participatory conservation practices or environmental projects. In other words, power is analyzed by signifying the role of discourse and the politics of the presentation of facts. Escobar urges the need to understand nature as a 'social construction' wherein language is 'an active agent' (Escobar 1996, 1999). Discourse is often created, owned and advanced by socially and culturally defined 
groups (operating at the global, national and local levels). For example, Khan and Lynch describe how bilateral and multilateral donor organizations, as well as the United Nations, endorse the language of decentralization and participation but in doing so "...made poverty responsible for the degradation of protected areas, not the capitalist mode of production" (2013: 113, emphasis in original). In this regard, participatory conservation is a product of socially mediated interests (Simon 2004), as members of social groups play an active role in the production, reproduction and transformation of participation through written forms and documents (Taylor 2013).

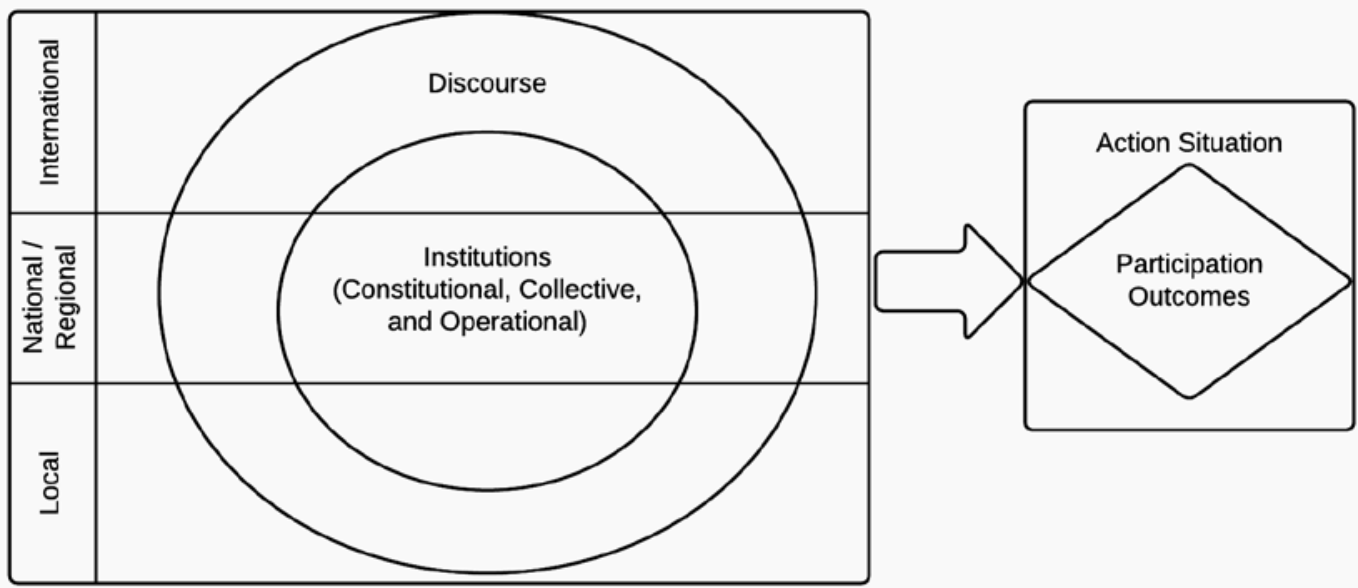

Figure 1: Multi-level framework of political ecology as applied across case studies.

Social groups that have been most successful at perpetuating and popularizing their discourse are those that have the power and the means to do so. In the context of environmental discourse (including the discourse of participation), for example, multilateral and international environmental agencies, donor agencies and other actors with access to scarce power resources (legal, financial, political) have been able to advance their interests, allowing their discourse to be translated into policy prescriptions and to shape institutional arrangements that guide access to, and use of environmental resources (Adger et al. 2002; Barr et al. 2009; Taylor 2013). A political ecology of participatory conservation is focused at this intersection of discourse and institutions.

\section{Institutions}

Institutions can be understood as "the humanly devised constraints that structure political, economic and social interaction" (North 1991:97) or "the rules of the game" (Ostrom 1990:3). Institutions are important because they are the most malleable among the different determinants of human-environment relations. It is through institutions that humans attempt to exercise control of natural resources and environmental regimes (Young 2008). Epstein et al. (2015) argue that institutions contribute to successful natural resource conservation by providing "fit" with social-ecological systems. Following Ostrom (2011), an institutional framework should identify the major types of structural variables that are present to some extent in these institutional arrangements, but whose values differ from one type of institutional arrangement to the next. Institutions are multi-level and include nested arrangements of decisions such that situations of broader scope (i.e., defining constitutional choices) can elicit a more or less participatory mode of behavior at lower levels of 
implementation. As outlined by McGinnis (2011), the different institutional levels require consideration in any institutional analysis include (from the higher level to the lowest level):

- Constitutional: the processes through which collective choice procedures are defined, including legitimizing and constituting all relevant collective entities involved in collective or operational choice processes;

- Collective choice: the processes through which institutions are constructed and policy decisions made, by those actors authorized to participate in the collective decisions as a consequence of constitutional choice processes; and,

- Operational choice: implementation of practical decisions by those individuals who have been authorized (or allowed) to take these actions as a consequence of collective choice processes.

Understanding the opportunities and constraints at these different levels, as well as at what points discourse influences and interacts, can provide insight into what shapes participatory conservation outcomes.

In an institutional analysis, the first step in analyzing a problem is to identify a conceptual unit - an action situation - that is used to describe, analyze, predict, and explain behavior within institutional arrangements. Action situations are the social spaces where individuals interact, exchange goods and services, solve problems, and dominate one another (Ostrom 2011). The action situation comes from a policy analysis diagnostic tool, the Institutional Analysis and Development framework (IAD), that has been used for the analysis of very different issues where humans interact within norms and rules that influence their choices, behaviors and decisions (Hess and Ostrom 2007; Kiser and Ostrom 1982), including a significant body of interdisciplinary research on local common property arrangements and environmental conventions (Ostrom 1990). The (IAD) has been extensively used for the study of CPRs and common-property regimes in the field of natural resource management (e.g. Agrawal 1999; Oakerson 1992; Ostrom et al. 1994) but also for other complex interdisciplinary research tasks, for example the study of government incentives, the analysis of institutional impacts on monitoring and evaluation in development projects (Gordillo and Andersson 2004) and institutional analysis of reforestation policies (Clement and Amezaga 2008). The IAD framework approach is used in such a large variety of empirical settings because it is helpful for identifying and rigorously analyzing the structure of a situation, in particular the influence of the rules, the essential characteristics of the actions and events taking place and the main actors, subjects, and communities involved (Ostrom 2011).

The IAD framework has notably been used to identify drivers of collective action in natural resource management. Its typology of rules provides a sound basis for understanding the role of institutions across multiple decision-making levels. However, a recurrent critique of institutional analysis is that it does not highlight the role of power and politics. To address this limitation, Clement (2010) proposes a modified "politicized" version of the IAD that takes into account the assessment of policy change and policy impacts, across multiple levels of governance with a focus on "why local factors matter" (Clement and Amezaga 2008). Following Clement's IAD interpretation, it is important to integrate analysis of multiple governance levels and to include political aspects of the structuring transmitted through discursive practices (Clement 2010; Hajer and Versteeg 2005). In our analysis, we set 'participation' as the center of the action situations observed in the different studies (Figure 1).

\section{The intersection of discourse and institutions}

Scholarship on community-based natural resource management (CBNRM) is an important subset of the participatory conservation literature that has identified local context as a key explanatory factor driving the effectiveness of a participatory intervention (Waylen et al. 2010). We argue that it is at the operational level of institutions - the very local level - that we see the misfit between the institution of participatory conservation, and the discourse that guides it. The operational level includes the social-cultural, political, economic and ecological contexts in which actors attempt to implement participatory programs. A key element of the operational level is the 'community', often identified as the local actor and recipient of devolved powers in participatory discourse. Often, the notion of community is simplified with most of the participatory approaches 
assuming that a community is a homogeneous entity. According to Barrow et al. (2002: 25), a "...community is usually defined as 'a social entity, bound by a common cultural identity, living within defined spatial boundaries and having a common economic interest in the resources of an area." Similarly, McCarthy (2005) notes that communities are often considered bounded, coherent social actors, rather than as terrains of struggle. This serves well to describe small social aggregations where the household and village level are the basis of organization of much of a rural area. Essentially, it typifies 'communities of place' where rural farmers are sedentary and reliant on arable land (Barrow et al. 2002).

However, in practice, communities seldom exist in a simplistic way and are characterized by their fluidity (Fabricius et al. 2005; Sayers and Elliot 2005; Siurua 2006). Everywhere, communities are continually being reworked by resettlements, migrations, livelihood practices and other factors (Barrow et al. 2002). Communities are highly complex and heterogeneous. They are differentiated in terms of social variation (e.g. gender relations), stratification (wealth and power), common interests, ethnicity and resource use (Barrow et al. 2002; Barr et al. 2006; Cooke and Kothari 2001; Hobley 1996). More often than not, the practice of participation suffers as the definition of community is conveniently skewed to favor the most powerful actor so that their vested interests are accommodated with little resistance.

The challenges of simply 'transferring' community-based conservation across contexts have been noted (Bixler and Taylor 2012), as well as the many barriers to participatory governance and transparent and accountable institutions that incorporate community interests and livelihood concerns (Western and Wright 1994). The CBNRM literature relies heavily on normative rather than empirical conceptualizations, and empirical studies often show that actual devolution and power-sharing from governments to community institutions is limited and, in some cases, non-existent despite its policy intent and rhetoric. As policy analysis of devolution and decentralization have indicated, the role of the state is still central in many cases of community-based natural resource conservation and management, much to the chagrin of CBNRM proponents.

\section{Methods}

The methodological nature of this research collaboration is grounded in an interdisciplinary effort to understand the dynamics of political ecology across a range of contexts and researcher experience. The researchers, who are from three different continents, were brought together at the Thor Heyerdahl Summer School (THSS) in Environmental Governance in June 2011. The first annual two-week THSS was hosted by the Department of International Environment and Development Studies, Noragric, at the Norwegian University of Life Science in Aas, Norway. The Summer School creates an arena for critical reflection on the present status of theory and practice in the field, and an opportunity to discuss alternatives to current developments and solutions. While participating in this summer school, the researchers began a process of discovery to uncover dramatic similarities and stark differences between their selected research case studies and the theory and practice of political ecology.

From this common ground, we developed a similar body of participatory indicators to assess the theory of participation in natural resource management across our cases (as discussed in the preceding section). This first collaborative step ensured consistency across the definitions of the indicators and criteria, and enabled a comparison of the key findings so that common conclusions could be developed across the studies. Despite the post-hoc nature of our comparative analysis, we find overwhelming areas of compatibility, comparability, and insight when applying a political ecology framework across the different case areas.

\section{Data collection}

Over four years and across the four case studies, 312 interviews were conducted with a very broad spectrum of stakeholders, including (but not necessarily limited to): pastoralists, ranchers, government officials, non-governmental organizations, policy makers, and key community leaders. Additional data was collected through participant observation and analysis of archival data and policy documents. It is important to note that what we present here is a comparative study, rather than a deep analytical analysis of the interviews in each case. For more depth on each case, we refer to the specific studies published (e.g., for Kenya see Khalif and Oba 2013 and Roba and Oba 2013; for Zambia see Mfune 2014; for China see Dell'Angelo 2012; and for the USA see Bixler and Taylor 2012). We compare these four cases on the basis that they provide compelling contrasts across geo-political contexts where the notion of participation is seen as being at the core of 
respective natural resource conservation policies or programs. Moreover, each case concentrates on a different type of natural resource. This not only shows how participation has been widely accepted and deployed in different geo-political contexts, but also across different resource types.

\section{Case Studies}

\section{Zambia: the Munyeta Reserve}

Conservation of natural resources in Zambia has historically been dominated by use of the protected area 'fortress conservation' model. However, over the past two decades, a shift in policy has seen the state embrace a discourse of participation that has triggered regime change in the management of protected areas. This transition, however, is characterized by contestations between various actors involved in it, as illustrated in the case of Munyeta Reserve (located in central Zambia). Munyeta Forest Reserve is part of the Miombo eco-region that is dominated by tree species belonging to the Brachystegia, Jubernardia and Isoberlina genera. Its range of hills and hydrological characteristics makes it an area of outstanding scenery. The area was designated a protected forest in 1980 for the purpose of protecting its rich biological resources, its range of hills and water catchments. Although the state adopted an exclusionary approach (i.e. fortress conservation), implementing restrictions was problematic given its size (with 12,000 hectares and a land surface boundary of $42 \mathrm{~km}$ ) and the complications involved in enforcement of forest rules and monitoring exploitation. As a result, over the last thirty years, the reserve has been characterized by extensive deforestation resulting from human activities including illegal settlements, charcoal production, livestock grazing and farming. Communities inside and outside the reserve depend on it for their livelihoods, but the state distinguishes these groups based on their legal status in the area. Those in the reserve are considered 'illegal settlers' or 'squatters', as human settlement in government reserves is illegal. This group is highly heterogeneous (culturally and economically) and most settlers have only recently moved into the reserve from various parts of the country. In contrast, the community outside the reserve is less culturally and economically diverse and comprises mostly one ethnic group (the Soli, who claim ownership to the reserve land) whose settlement in the area predates the establishment of the reserve. The degraded state of the reserve and the multiple claims to its resources has prompted a shift in natural resource management strategies from the fortress conservation model towards participatory natural resource management. In this regard, the state has begun the process of transforming Munyeta Forest Reserve into a joint forest resources management (JFM) area to allow local participation in the process. The purpose of instituting such reforms is to halt the degradation of forest resources by involving local actors in natural resource governance. The livelihoods of these local actors are identified as central to the degradation occurring in the reserve.

\section{Kenya: the Biliqo-Bulesa Conservancy}

In Northern Kenya, community conservancies have been promoted as forms of participatory wildlife management, although implementation has been problematic and it remains controversial. Like other participatory regimes, the main rationale for engaging local communities in wildlife management is to achieve the duel objectives of wildlife conservation and sustainable development. In Northern Kenya, common justification for this strategy is that pastoralism, the traditional source of livelihood, is barely surviving under external pressure, including demographic growth and a climate-related reduction in rainfall over the last few years. In practice, implementation of participatory environmental management faces daunting practical challenges that hinder achievement of the broader objectives. This is the case in the Biliqo-Bulesa wildlife conservancy in Isiolo District. Northern Kenya is a marginal environment with low rainfall and high spatial temporal variability. Water, which is an important determinant of livestock and wildlife distribution across the rangeland, is very scarce. The landscape is heterogeneous with remote patches of key grazing resources. The conditions necessitate daily and seasonal herd mobility. The community living around Biliqo and Bulesa administrative wards, belonging to the Waso Boran, established the conservancy in 2007. Families and households in this community enjoy strong clan ties and other relationships that influence decisions on the use of grazing resources and these pastoralists practice reciprocity to access neighboring rangeland and water resources. The clans share similar customs, norms and understanding of spatial and temporal resource variability. This is part of their cultural repertoire for deliberation and implementation of popular strategies for 
resource governance. Biliqo-Bulesa is a member of a network of community conservancies in northern Kenya under the umbrella Northern Rangeland Trust. It also enjoys supports from the Kenya Wildlife service that is the national institution with a mandate to manage wildlife. The 'core conservation areas' (to be set aside exclusively for wildlife) would otherwise be communally owned with no restriction for pastoralists to graze them. However, the position of pastoralists who oppose the conservancy is that exclusion from accessing key grazing resources around Biliqo-Bulesa will have negative impacts on their herd management. Concern is over access to dry season fodder and important salt licks. Increased year-round grazing pressure in the area has meant conservancy members have had to employ local wardens to protect wildlife and enforce access rules and regulations.

\section{People's Republic of China, Qinghai: the Sanjiangyuan area}

Starting in the early 2000s the Chinese central government implemented natural resource conservation and environmental governance programs in the Tibetan rangelands of the Qinghai-Tibetan plateau. The Sanjiuangyuan area is $363,000 \mathrm{~km}^{2}$ in size, and covers $~ 50 \%$ of Qinghai province, with an average altitude of 4000 meters. Over $59 \%$ of its land are grasslands ( $\mathrm{Li}$ et al. 2012) and it contains the watersheds of the three major rivers of China - the Mekong, the Yangtze and the Yellow (Dell'Angelo 2012; Yeh 2009). Due to its large water reserves the Sanjiangyuan area has been referred to as the 'Water Tower of Asia' and it is estimated over 60 billion $\mathrm{m}^{3}$ of water annually are provided through its rivers (Li et al. 2012; Shen and Tan 2012). Tibetan pastoralist are the prevalent population in the rangelands, and their presence has been traced, with ecological evidence, back 8,800 years (Miehe et al. 2009). Recently, a multiplicity of factors including demographic pressure, ecological disturbances, and policy and institutional arrangements have led to environmental pressure on the rangelands. Government policies target pastoral activity of the Tibetan nomads as a major stressor for the rangelands and therefore the watershed, and an extensive program of resettlement and sedentarization has been implemented. The Chinese government claims that resettlements are voluntary, and that the Tibetan nomads are actively involved in a process of environmental restoration and economic development (Dell'Angelo 2013; Ptackova 2011).

\section{United States: Montana's Blackfoot Valley}

The Blackfoot Valley in Montana lies at the southern end of what is known as the Crown of the Continent Ecosystem, an 18 million-acre area (7,284,300 ha) of the Northern Rocky Mountains extending into portions of Canada and the United States. The Blackfoot Watershed totals about 1.5 million acres $(607,000$ ha), with private ranchlands ( $24 \%$ of the watershed) comprising most of the foothills and lower valley and the upper, forested and mountain areas being owned and managed by the state of Montana (5\% of the watershed) and Federal (49\% of the watershed) governments. The Plum Creek Timber Company owns the remaining 20\% of the watershed. Water resource conflicts are prominent in the western United States (Sabbatier et al. 2005), and recreational access, water quality and water quantity problems often serve as the impetus for the establishment of watershed partnerships such as the one in the Blackfoot (Bixler and Taylor 2012). This approach to environmental governance has been a response to ecological degradation of water resources, and to a political stalemate resulting from traditional approaches to environmental conflict resolution (largely through litigation). Within the watershed are seven residential communities, with an additional four 'communities of interest': ranchers, government agencies, land-trusts and recreationists. The diverse nature of land ownership equates to diverse ownership of water rights and uses.

\section{Results: the influence of institutions and discourses shaping participatory conservation outcomes}

\section{Discourse}

Across our cases, we identify two different discourses driving participation: (1) a reflexive reaction to centralized state control, and (2) participation as a response to environmental degradation. In Zambia and Montana, a reaction to state control and the narrative of an 'untouched', 'fragile', and 'pristine' environment that 'requires state control' mobilized local actors, who argued that the land was historically considered a tribal commons (Zambia) and a working landscape (USA) from which local actors derive livelihood benefits. 
Interestingly, in both cases the tensions between local and state actors led to opportunities when political and economic circumstances changed. In Kenya and China, the discourse driving participation is largely driven by long-standing concerns over biodiversity (Kenya) and environmental restoration (China). In line with dominant narratives, local actions are driving undesirable environmental change. This justifies the creation of conservancies and resettlement programs (Kenya and China, respectively), with both using the label of engagement and participation by affected local peoples. Moreover, in both cases, local authorities describe conservation intervention as a positive transition in shifting to a modern (and sedentary) system of livelihood production, in which communities themselves are the main actors and not passive recipients.

\section{Institutions}

We found changing institutions being shaped by, and at the same time shaping, the discourses being used. For example, the protected area model used in Zambia serves as the constitutional and collective choice body that determines who has the right to access or use resources in the reserve. These rules guiding resource management exclude local communities from accessing resources in the reserve and participating in the decisionmaking process surrounding its management. However, these rules are changing, at least rhetorically, under Joint Forest Management (JFM). In JFM, the discourse of participation creates new aggregate arrangements that include communities. The JFM committee, acting as a new collective choice body has now put in place new rules that have been framed as 'JFM' rules.

By contrast, the rangeland of northern Kenya is communally owned, and there is no restriction on grazing wherever it is abundant. Access and resource management is regulated by traditional customary (operational) rules under leadership of the local elders' council (Jarsa dheda). Creation of the conservancy introduces new access rules and changes the stewardship from local elders to the conservancy officials. The officials and conservancy committee selected from the local users holds the most powerful position in its operation. They have authority over day-to-day management including recruitment and supervision of community game wardens. Although theoretically the members in this position ought to change on a regular basis, the process is not always transparent.

In China, strong institutions clearly exist at the constitutional level that defines who can access the resource. This is based on ethnicity and socio-economic criteria. The main actors, Tibetan nomads, have authority only at the village government level. Nomads participate in village assemblies (but only men). Nomads have no representation in the higher levels of decisions that affect access to land. The nomads tend to respect the traditional village and inter-villages rules rather than the ones imposed by government. The level of shared information regarding land tenure and grazing information is very high in the village, and not respecting local operational rules leads to discussion and local sanctions in the village assemblies, without government involvement.

In the complex system of federalism in the United States, there are a myriad statutory and administrative rules overlaid upon each other and operating in a particular geographic area. However, the management actions produced by collaborative institutions (such as the non-profit watershed organization in this case) provide new sets of institutional rules governing the use of resources at an operational level within the watershed.

The power of participatory conservation is predicated on the belief that coupled development and conservation outcomes are achievable, and across all cases we find a strong link to economic development (see Vaccaro et al. 2013). Zambia experienced significant economic downturn in the 1990s followed by biting structural adjustment policies, that left many people unemployed and resettlement within the Munyeta reserve. Longstanding political and economic marginalization in Kenya, as well as remnants of a secessionist war (Whittaker 2008), has led to current high levels of poverty and livelihood insecurity in the region. This is indicated by smaller herd size at the household level. In Qinghai, China, 39 out of 46 rural counties were officially classified as "poverty stricken" over a decade ago (Qinghai Statistical Yearbook 2001 in Goodman, 2004). Participatory conservation efforts have been catalyzed by the slogan Open up the west through rebuilding a green west, a five-year Plan based on environmental sustainability, new infrastructure, and better transport and communication (Goodman 2004). Qinghai's development strategy is part of a wider Open up the West campaign (xibu da kaifa) introduced by the CCP in 1999 to develop the economy and reduce the 
economic and infrastructural gaps between the rich East and the poorer interior provinces in China (Yeh 2005). In Montana, ranching and forestry livelihoods have and still tend to dominate the social and cultural milieu of the watershed (and to a lesser extent, recreation and tourism activities are increasing). However, habitat fragmentation and loss of open space through exurban development are threatening some of the livelihood options available for local residents. In all cases, local actors have become dependent on exploitation of local resources for agriculture and other extractive activities. Likewise, in all cases we find political mistrust by local people of state authorities and conservation programs that have external interests behind them, and are trying to dislodge the local in favour of their own projects.

\section{The political ecology of participatory conservation}

We found new 'action situations' being created across three of the four cases (Kenya, Montana, and Zambia). The 'JFMs', 'conservancies', and 'watershed collaboratives' provide an arena for local actors' interaction with the state. These arenas are construed as shared decision-making spaces with accompanying distribution of power and responsibilities over natural resources between the state and local communities. The situation in the Chinese case is quite different, and takes into account the level of participation of nomads as it varies in relation to resettlement policies.

These 'spaces', however, vary considerably in the ways they are structured and in their outcomes. In practice, JFM in Zambia is structured in such a way that the state continues to be the main driver of the process, prescribing the goals of conservation and the conditions for local actor participation. By drawing on resources of power (e.g. legal statutes, political power and technical knowledge) the state, through its Forestry Department, continues to retain control of the JFM process. By being prescriptive, the state is able to preserve and advance its interests such as including the retention of revenue generated from the exploitation of forest products and the exclusion of agricultural practices from the reserve. At the same time, local actors (i.e. traditional leaders and reserve residents) have constrained decisionmaking powers (and their interests are ignored). They contest state decisions through local resistance, and defiance of new rules by expanding their agricultural plots in the reserve.

The conservancy in Kenya disrupts traditional social networks that served as an economic cushion, and also as the foundation of social cohesion. The new rules of the conservancy replace customary rules and creates new forms of stratification and power relations, increasing vulnerability and conflict. In addition to harboring a pro-conservation mindset, the people responsible for decision making lack in-depth local knowledge of the functioning of the socio-ecological system that traditionally informs customary management practices. A very similar situation occurs in 'watershed collaboratives' in the US, where new forms of stratification and power relations emerge as certain relationships strengthen between private and public entities at the exclusion of other groups or voices.

In the 'watershed collaboratives', the natural resource management agencies largely operate on legislative mandates to conserve habitat and water resources under the U.S. federal Endangered Species Act and other statutes (for example the minimum levels of flow mandated to sustain endangered fish stocks), which also comes with regulatory power. Those individuals and groups with working relationships to the regulatory authorities are often the beneficiaries of favorable policies and economic returns. Similarly in Kenya, the members of the conservancy are the true beneficiaries. Non-member pastoralists, although having historical claims, contest the conservancies because they can limit their access to key dry season grazing resources and salt licks within the area (Roba and Oba 2013). In Zambia, despite the JFM, the heterogeneity of the community in the reserve, pre-existing customary rules and tribal claims to the reserve land by the Soli tribal community (both outside and inside the reserve) are a major deterrent to the establishment of a new natural resource regime that enables 'participation.'

\section{Discussion: participation as an outcome}

Many scholars have highlighted the de-politicization of participation, both as a discourse and as a process (Cornwall and Brock, 2005; Hickey and Mohan 2005) and the influence of broader political forces as a key driver for social and conservation outcomes (Blaikie 2006). Whereas institutional theorists have extensively explored the rules, community attributes and local biophysical conditions driving community 
participation (Ostrom 1990; 1999), few studies have linked these factors with the broader discursive and local context in which participation projects are embedded. Development and conservation studies have interrogated the discourse of participation, but often using a single country or single case context. While producing rich indepth analysis, these studies have often lacked a comparative analysis of how certain variables can be abstracted and how others remain context-specific. Our analysis indicates striking similarities between some of the variables across our cases. However, without a nuanced appreciation of how institutions intersect with local, national, and international discourses, participation has shortcomings as a blanket policy option. This is the 'participation as panacea' challenge highlighted by Ostrom and Cox (2011).

For example, we find striking similarities between Montana and Zambia on the one hand, and Kenya and China on the other (see Table 2). The biophysical conditions variable (the first having a stationary resource and resource use, and the other being mobile pastoralists) has a large influence on the nature of participation and the institutions governing these systems. Water, forests, grazing resources, agricultural landscapes and other resource systems show important differences in defining the meaning of participation. Institutions are decided through a process (or lack of process) contingent on the nature of the resource. Importantly, and as indicated elsewhere, clear tenure arrangements (i.e. clear property rights) create a less conflictive local context where rights, authorities, and obligations are more easily defined (Ostrom 1990). In Kenya and China, the nature of mobile land use and the interests of different pastoral groups who enjoy usufruct rights need consideration. In China, with its strong state and a sensitivity to Tibetan political autonomy, the nature of participation is 'passive' at best (see Table 1, Hobley 1996).

\begin{tabular}{|c|c|c|c|c|}
\hline & Zambia & Kenya & China & USA \\
\hline $\begin{array}{l}\text { Biophysical } \\
\text { Resource }\end{array}$ & Stationary, forest & Pastoral, grazing & Pastoral, grazing & Stationary, water \\
\hline Discourse & Local resistance & $\begin{array}{l}\text { Tragedy of the } \\
\text { commons }\end{array}$ & $\begin{array}{l}\text { Tragedy of the } \\
\text { commons }\end{array}$ & Local resistance \\
\hline $\begin{array}{l}\text { Institutions } \\
\text { (constitutional } \\
\text { level) }\end{array}$ & $\begin{array}{l}\text { Transition to new } \\
\text { institutional } \\
\text { arrangements }\end{array}$ & $\begin{array}{l}\text { Tensions between } \\
\text { customary rules and } \\
\text { conservancy rules }\end{array}$ & $\begin{array}{l}\text { Rules that restrict } \\
\text { access }\end{array}$ & $\begin{array}{l}\text { Shape local } \\
\text { arrangements }\end{array}$ \\
\hline $\begin{array}{l}\text { Institutions } \\
\text { (operational } \\
\text { level) }\end{array}$ & $\begin{array}{l}\text { Local livelihoods, } \\
\text { competing ethnic and } \\
\text { socio-economic } \\
\text { groups }\end{array}$ & $\begin{array}{l}\text { Local livelihood, } \\
\text { traditional clan } \\
\text { cooperation across } \\
\text { spatial-temporal } \\
\text { dimensions }\end{array}$ & $\begin{array}{l}\text { State-centric } \\
\text { economic } \\
\text { development }\end{array}$ & $\begin{array}{l}\text { Local conservation } \\
\text { to avert outside } \\
\text { development } \\
\text { threats }\end{array}$ \\
\hline $\begin{array}{l}\text { Action } \\
\text { Situation }\end{array}$ & $\begin{array}{l}\text { Joint Forest } \\
\text { Management }\end{array}$ & Conservancies & $\begin{array}{l}\text { Settlement } \\
\text { programs }\end{array}$ & $\begin{array}{l}\text { Watershed } \\
\text { collaboratives }\end{array}$ \\
\hline Participation & $\begin{array}{l}\text { Functional } \\
\text { participation }\end{array}$ & $\begin{array}{l}\text { Functional } \\
\text { participation }\end{array}$ & $\begin{array}{l}\text { Passive } \\
\text { participation }\end{array}$ & $\begin{array}{l}\text { Interactive } \\
\text { participation }\end{array}$ \\
\hline
\end{tabular}

Table 2: Summary of results 
In Zambia, institutional structures have been established to guide participation. However, despite local actors being represented on joint forest management committees, they have been made to conform to bureaucratic regulations developed by the state, such that the rules still represent the decisions of external actors rather than local ones. Their participation is, in practice, a means to achieve goals set by external actors (i.e. the state). Consequently, local actors are merely co-opted in decisions made by the state and other external actors. Applying Hobley's framework, this is more like functional participation (see also Buchy and Race 2001; Jones 2006). Although local actors are not ignored completely in decision-making, they still have very limited decision-making power because of the influence of more powerful actors in the process.

All of these cases illustrate how unequal power relations between actors operating at various levels (e.g. between the state and local communities) involved in participatory programs favor the interests of the more powerful. The challenge, however, is not limited to bettering relationships between state actors (and NGOs) and the community, but also between members of the local community itself. The Kenyan case, for example, shows how the benefits of natural resources conservation can easily be skewed in favor of one group of people at the expense of other groups in the community itself. Participation by local peoples in Kenya is 'functional' in its aim to meet goals and objectives imposed from the outside.

Similarly in Montana, 'participation' enables a certain social segment to achieve their livelihood aims while excluding the claims of other, and equally valid, social groups and interests. This finding supports others who recognize that the notion of 'community' in the discourse of participation may serve to conceal the power relations within communities, and mask biases in interests and needs based on ethnicity, class, religion, gender and other factors (Agrawal and Gibson 1999; Barrow et al. 2002; Brown 2003; Cooke and Kothari 2001). This suggests the need for participatory processes to engage critically with the notion of community in order to understand the various interests concealed by the term.

We find similar, very interesting comparisons in the discourse used to enable participatory conservation in different cases. Again, we find similarities between Zambia and Montana, and China and Kenya. In the Northern Kenyan case, local communities were convinced to by 'participatory conservation' without adequate knowledge of the long term implications for their livelihood systems, and for the unique bio-cultural landscape that they have managed for centuries. Participation was driven less by local resistance and more from a longstanding enactment of strategies to avert the 'tragedy of the commons.' Similarly, in China we find participation being driven by a desire to avert a 'tragedy of the commons', but where participation is imposed, since the state-centric vision of watershed restoration is discordant with the nomadic lifestyle of local actors and the existing institutional arrangements that govern the organization of their livelihoods. The rules-in-use guiding participation in the watershed preservation program have not resulted in any transfer of decisionmaking powers to local actors. Interestingly, the discourse of 'watershed restoration' in Montana has catalyzed conservation and the engagement of local participation. In this case, however, we find 'participation' emerging from a context of local resistance rather than it being a response to a pre-existing narrative of resource degradation and scarcity.

\section{Conclusions}

In spite of strong rhetoric of participation in all four cases, we find significant variation of outcomes in the ways participatory discourse was implemented across contexts. While this is unsurprising in many ways, it does raise concerns about the linkages between conservation theory, policy and programmatic efforts of implementation, and local livelihood and conservation outcomes. It is not evident that the touting of participation as a panacea for more sustainable natural resource management by large international donors and multi-national bodies has led to better ourcomes. Theories of participatory governance need to be less generalized and more situated within the contours of place-based institutional and environmental histories.

The challenges of conducting a study such as this are clear and obvious. Despite a general and easily understandable theory of participation, institutional factors shape outcomes and these vary across a wide spectrum. We have looked at how the institutional dynamics, discourses, and action situations in different geopolitical contexts shape participation, and the social and ecological implications of these participatory conservation interventions. We find similarities across contexts, but also important differences. The value in a study such as this is not the knowledge it generates about particular cases, but rather what it can tell us about conservation programs writ-large. We find that the drive for participation comes from two primary sources: 
local resistance to state control of natural resources (as the literature confirms), but also a traditional tragedy of the commons arguments that provides the rationale for some form of intervention. In the latter situation, Cooke and Kothari's (2001) argument appears to hold; despite the rhetoric of local actor empowerment and the democratic language underpinning participatory programs, it is more likely that participation fosters tyranny than democratic ideals. This happens when participation is framed in such a way that powerful actors continue to override local actors' interests, and constrain their spaces for decision making.

Although participation has been globally applied as a panacea for natural resource management, this study illustrates the gap between its theory and implementation, and illustrates the role of political ecology in shaping institutional dynamics. Through this lens, we reveal the dialectical process of conservation, since the very institutions that participation is intended to build create resistance to those that orchestrate it. Conservation theory, and theories of participatory governance, must consider these dynamics if we are to move conservation forward in a way that authentically incorporates local level livelihood concerns.

\section{References}

Adisu, M., and J. Croll. 1994. Human and social imperatives for environmental and resource management in Southern Africa. In ICUN Proceedings of Round Table Conference held at Kwa Maritime Camp, Pilanesberg National Park, Northwest Province, South Africa, 14-18 August 1994.

Adger N.W., T.A. Benjaminsen, K. Brown, and H. Svarstad. 2002. Advancing a political ecology of global environment discourses. Development and Change 32 (4): 681-715.

Agrawal, A. 1999. Greener pastures: politics, markets, and community among a migrant pastoral people. Durham, NC: Duke University Press.

Agrawal, A. and C.C. Gibson. 1999. Enchantment and disenchantment: the role of community in natural resource conservation. World Development 27: 629-649.

Arnstein, S.R. 1969. A ladder of citizen participation. Journal of the American Planning Association 35 (4): 216-224.

Bryant, R. and S. Bailey. 1997. Third world political ecology: an introduction. London: Routledge.

Banerjee, S.B. 2001. Corporate citizenship and indigenous stakeholders: exploring a new dynamic of organisational-stakeholder relationships. Journal of Corporate Citizenship 1(17): 39-55.

Barr, C., I.J. Resosudarmo, J. McCarthy, and A. Dermawan (eds). 2006. Decentralisation of forest administration in Indonesia: implications for forest sustainability, economic development and community livelihoods. Bogor: CIFOR.

Barrow, E., J. Clarke, I. Grundy, K.R. Jones, and Y. Tessema. 2002. Analysis of stakeholder power and responsibilities in community involvement in forest management in Eastern and Southern Africa. Nairobi: IUCN.

Berkes, F. 2004. Rethinking community-based conservation. Conservation Biology 18: 621-630.

Berkes, F. 2010. Devolution of environment and resources governance: trends and futures. Environmental Conservation 37 (4): 489-500.

Biggs, S., 1989. Resource-poor farmer participation in research: a synthesis of experiences from nine national agricultural research systems. OFCOR Comparative Study Paper 3. The Hague: International Service for National Agricultural Research.

Bixler, R.P. 2013. The political ecology of local environmental narratives: power, knowledge, and Mountain Caribou conservation. Journal of Political Ecology 20: 273-285.

Bixler, R.P. and P.L. Taylor. 2012. Toward a community of innovation in community-based natural resource management: insights from Open Source software. Human Organization 71 (3): 234-243.

Blaikie, P.M. 2006. Is small really beautiful? community-based natural resource management in Malawi and Botswana. World Development 34 1942-1957.

Botes, L., and D. van Rensburg. 2000. Community participation in development: nine plagues and twelve commandments. Journal of Community Development 35: 41-58. 
Brosius, J.P., A.L. Tsing, and C. Zerner. 1998. Representing communities: histories and politics of community-based natural resource management. Society and Natural Resource Management 11: 157168.

Brown, K., 2003. Three challenges for a real people-centered conservation. Global Ecology and Biogeography 12: 89-92.

Buchy, M. and D. Race. 2001. The twists and turns of community participation in natural resource management in Australia: what is missing? Journal of Environmental Planning and Management 44: 293-308.

Campbell, L. M. 2000. Human need in rural developing areas: perceptions of wildlife conservation experts. Canadian Geographer / Le Géographe Canadien 44: 167-181.

Clement, F. 2010. Analysing decentralised natural resource governance: proposition for a "politicised" institutional analysis and development framework. Policy Sciences 43 129-156.

Clement, F., J.M. Amezaga. 2008. Linking reforestation policies with land use change in northern Vietnam: why local factors matter. Geoforum 39: 265-277.

Clement, F. and J.M. Amezaga. 2009. Afforestation and forestry land allocation in northern Vietnam: analysing the gap between policy intentions and outcomes. Land Use Policy 26: 458-470.

Cooke, B. and U. Kothari (eds.). 2001. Participation: the new tyranny? London: Zed Books.

Cornwall, A. and K. Brock. 2005. What do buzzwords do for development policy? A critical look at "participation", "empowerment" and "poverty reduction". Third World Quarterly 26: 1043-1060. draft

Dell'Angelo, J. 2012. The sedentarization of Tibetan nomads: conservation or coercion. In H. Healy, J. Martínez-Alier, L. Temper, M. Walter and J.F. Gerber (eds). Ecological economics from the ground up. London: Routledge. Pp 309-322.

Epstein, G., Pittman, J., Alexander, S.M., Berdej, S., Dyck, T., Kreitmair, U., Raithwell, K.J., VillamayorTomas, S., Vogt, J. and D. Armitage. 2015. Institutional fit and the sustainability of social-ecological systems. Current Opinion in Environmental Sustainability 14: 34-40.

Escobar, A. 1996. Constructing nature: elements for a poststructural political ecology. In R. Peet and M.J. Watts (eds). Liberation ecologies: environment, development, social movements. New York: Routledge.

Escobar, A. 1999. After nature: steps to an antiessentialist political ecology. Current Anthropology 40 (1): 130.

Fabricius, C. and S. Collis. 2007. Community based natural resource management: governing the commons. Water Policy 9 (Supplement 2): 83 -97.

Forsyth, T., M. Leach, and I. Scoones. 1998. Poverty and environment: priorities for research and policy. An overview study prepared for the United Nations Development Program and European Commission. Institute of Development Studies, Sussex, United Kingdom.

Forsyth, T., 2003. Critical political ecology: the politics of environmental science. London: Routledge.

Gezon, L., S. Paulson. 2005. Place, power, difference: multiscale research at the dawn of the twenty-first century. In L. Gezon and S. Paulson (eds.) Political ecology across spaces, scales, and social groups. New Jersey: Rutgers University Press. Pp. 1-16.

Gillson, L., 2004. Testing non-equilibrium theories in savannas: 1400 years of vegetation change in Tsavo National Park, Kenya. Ecological Complexity 1: 281-298.

Goodman, D.S.G. (ed.), 2004. China's campaign to "open up the West": national, provincial and local perspectives. Cambridge: Cambridge University Press.

Gordillo, G. and K. Andersson. 2004. From policy lessons to policy actions: motivation to take evaluation seriously. Public Administration and Development 24:305-320

Grimble, R. and M. Laidlaw. 2002. Biodiversity management and local livelihoods: Rio +10 . Overseas Development Institute: Natural Resource Perspectives 73: 1-4.

Habermas, J. 1984. The theory of communicative action: reason and the rationalization of society. Boston: Beacon Press.

Hajer, M.A. 1996. The politics of environmental discourse: ecological modernization and the policy 
process. Oxford: Oxford University Press.

Hajer, M. and W. Versteeg. 2005. A decade of discourse analysis of environmental politics: achievements, challenges, perspectives. Journal of Environmental Policy and Planning 7:175-184.

Hardin, G., 1968. The tragedy of the commons. Science 162: 1243-1248.

Hickey, S. and G. Mohan. 2005. Relocating participation within a radical politics of development. Development and Change 36: 237-262.

Hess, C. and E. Ostrom. 2007. Understanding knowledge as a commons: from theory to practice. Cambridge, MA: The MIT Press.

Hobley, M., 1996. Participatory forestry: the process of change in India and Nepal. ODI Rural Development Forestry Study Guide 3. London: Overseas Development Institute.

Hulme, D. and M. Murphree. 1999. Communities, wildlife and the "new conservation" in Africa. Journal of International Development 11: 277-285.

Hurley, J.M., C. Ginger, and D.E. Capen. 2002. Property concepts, ecological thought, and ecosystem management: a case of conservation policymaking in Vermont. Society and Natural Resources 15: 295312.

Jones, S., 2006. A political ecology of wildlife conservation in Africa. Review of African Political Economy 33: 483-495.

Kepe, T., J.-F. Bissonnette, and D.J. Roberts. 2008. Why are students attracted to political ecology? Environment and Planning A 40: 2539-2543.

Kiser, L. and E. Ostrom. 1982. The three words of action: a metatheoretical synthesis of institutional approaches. In Ostrom, E. (ed.) Strategies of political inquiry. Thousand Oaks: Sage. Pp 179-222.

Khalif, Z.K. and G. Oba. 2013. 'Gaafa dhaabaa - the period of stop': narrating impacts of Shifta insurgency on pastoral economy in northern Kenya, c. 1963 to 2007. Pastoralism: Research, Policy and Practice 3: 14.

Khan, M.T. 2013. Theoretical frameworks in political ecology and participatory nature/forest conservation: the necessity for a heterodox approach and the critical moment. Journal of Political Ecology 20: 461-472.

Khan, M.T. and T. Lynch. 2013. The genealogy of contemporary nature/forest conservation. Human Geography. 6(3): 106-120.

Lankford, B. and T. Beale. 2007. Equilibrium and non-equilibrium theories of sustainable water resources management: dynamic river basin and irrigation behaviour in Tanzania. Global Environmental Change $17: 168-180$.

Lawrence, A., 2006. No personal motive? Volunteers, biodiversity, and the false dichotomies of participation. Ethics, Place and Environment 9: 279-298.

Larson, A. and F. Soto. 2008. Decentralization of natural resource governance regimes. Annual Review of Environment and Resources 33: 213-239.

Li, X. L., G. Brierley, D.J. Shi, X.L. Xie, and H.Q. Sun. 2012. Ecological protection and restoration in Sanjiangyuan National Nature Reserve, Qinghai Province, China. In Higgitt, D.L. (ed.) Perspectives on Environmental Management and Technology in Asian River Basins. Dordrecht: Springer. Pp. 93-120.

McCarthy, J. 2005. Devolution in the woods: community forestry as hybrid neoliberalism. Environment and Planning A 37: 995-1014.

McGinnis, M.D. 2011. Networks of adjacent action situations in polycentric governance. Policy Studies Journal 39 (1): 45-72.

Mery, G. 2005. Forests in the global balance: changing paradigms. International Union of Forest Research Organisations, Vienna, Austria.

Mfune, O. 2014. Managing common pool resources without state support: insights from Shisholeka community in Central Zambia. Environment, Development, and Sustainability 16 (6): 1263-1280.

Miehe, G., S. Miehe, K. Kaiser, C. Reudenbach, L. Behrendes, L. Duo, and F. Schlütz. 2009. How old is pastoralism in Tibet? An ecological approach to the making of a Tibetan landscape. Palaeogeography, Palaeoclimatology, Palaeoecology 276(1) 130-147. 
Nelson, F. (ed.) 2010. Community rights, conservation and contested land: the politics of natural resource governance in Africa. London: Earthscan.

North, D.C. 1991. Institutions. Journal of Economic Perspectives, 5 (1): 97 - 112.

Oakerson, R.J. 1992. Analyzing the commons: a framework. In Bromley, D.W. (ed.) Making the commons work: theory, practice, and policy. San Francisco: ICS Press.

Ostrom, E. 1990. Governing the commons: the evolution of institutions for collective action. Cambridge: Cambridge University Press.

Ostrom, E. 1999. Coping with tragedies of the commons. Annual Review of Political Science 2: 493-535.

Ostrom, E. 2011. Background on the institutional analysis and development framework. Policy Studies Journal 39: 7-27.

Ostrom, E. and M. Cox. 2011. Moving beyond panaceas: a multitiered diagnostic approach for socialecological analysis. Environmental Conservation 37 (4): 451-463.

Ostrom, E., R. Gardner, and J. Walker. 1994. Rules, games, and common-pool resources. Ann Arbor, MI: University of Michigan Press.

Ptackova, J. 2011. Sedentarisation of Tibetan nomads in China: implementation of the Nomadic Settlement Project in the Tibetan Amdo area; Qinghai and Sichuan Provinces. Pastoralism: Research, Policy and Practice 1(1): 1-11.

Reed, M. 2008. Stakeholder participation for environmental management. Biological Conservation 141: 24172431.

Ribot, J. 2002. Democratic decentralization of natural resources: institutionalizing popular participation. Washington D.C.: World Resources Institute.

Ribot, J.C., A.R. Magalhães, and S.S. Panagides. 2005. Climate variability, climate change, and social vulnerability in the semi-arid tropics. Cambridge: Cambridge University Press.

Rinzin, C., W.J.V. Vermeulen, M.J. Wassen, and P. Glasbergen. 2009. Nature conservation and human wellbeing in Bhutan: an assessment of local community perceptions. The Journal of Environment Development 18: 177-202.

Roba, H. G. and G. Oba. 2013. Understanding the role of local management in vegetation recovery around pastoral settlements in Northern Kenya. Environmental Management 51: 838-849.

Robbins, P. 2004. Political ecology: a critical introduction. Oxford: Wiley-Blackwell.

Roe, D., Nelson F., and C. Sandbrook. 2009. Community management of natural resources in Africa: impacts, experiences and future directions. London: International Institute for Environment and Development.

Rowe, G. and Frewer, L. 2000. Public participation methods: a framework for evaluation in science. Technology and Human Values 25: 3-29.

Sabatier, P.A., W. Focht, M. Lubell, M., Z. Trachtenberg, A. Vedlitz, and M. Matlock (eds.). 2005. Swimming upstream: collaborative approaches to watershed management. Cambridge, MA: MIT Press.

Sayer, J. and Elliot, C. 2005. Re-inventing forests for the $21^{\text {st }}$ century. In Mery G., R.I. Alfaro, M. Kanninen and M. Lobovikov (eds.). Forests in a global balance - changing paradigms. IUFRO World Series 17. Vienna: IUFRO. Pp. 39-47.

Shen, X., and J. Tan. 2012. Ecological conservation, cultural preservation, and a bridge between: the journey of Shanshui Conservation Center in the Sanjiangyuan region, Qinghai-Tibetan Plateau, China. Ecology and Society 17(4), 38.

Scherr, S.J. 2000. A downward spiral? Research evidence on the relationship between poverty and natural resource degradation. Food Policy 25 479-498.

Scott, J. 1998. Seeing Like a state: how certain schemes to improve the human condition have failed. New Haven, CT: Yale University Press.

Simon, R.B. 2004. Political ecology of living aquatic resources in Lao PDR. PhD Dissertation. University of Sydney, Australia.

Simsik, M.J. 2002. The political ecology of biodiversity conservation on the Malagasy Highlands. GeoJournal 58: 233-242. 
Siurua, H. 2006. Nature above people: Rolston and "fortress" conservation in the south. Ethics and the Environment 11: 71-96.

Stringer, L.C. 2009. Testing the orthodoxies of land degradation policy in Swaziland. Land Use Policy 26: $157-168$.

Sullivan, S. and K. Homewood. 2004. Natural resources: use, access, tenure and management. In Potts D. and T. Bower-Bowyer (eds.) Eastern and Southern Africa: development challenges in a volatile region. London: Addison Wesley Longman. Pp118-166.

Taylor, S. 2013. What is discourse analysis? London: Bloomsbury.

Vaccaro, I., O. Beltran, P.A. Paquet. 2013. Political ecology and conservation policies: some theoretical genealogies. Journal of Political Ecology 20: 255-272.

Waylen, K.A., A. Fischer, P.J. McGowan, S.J. Thirgood, E.J. Milner-Gulland. 2010. Effect of local cultural context on the success of community-based conservation interventions. Conservation Biology 24 (4):1523-1739.

Western, D. and M. Wright. 1994. Natural connections: perspectives in community based conservation. Washington, D.C.: Island Press.

Whittaker, H. 2008. Pursuing pastoralists: the stigma of shifta, during the 'Shifta War' in Kenya 1963-1968. Eras Journal 10.

Xu, J., Y. Yang, Z. Li, N. Tashi, R. Sharma, and J. Fang. 2008. Understanding land use, livelihoods, and health transitions among Tibetan nomads: a case from Gangga Township, Dingri County, Tibetan Autonomous Region of China. Ecohealth 5 104-114.

Yeh, E. 2005. Green governmentality and pastoralism in Western China: converting pastures to grasslands. Nomadic Peoples 9: 9-30.

Yeh, E.T. 2009. Greening western China: a critical view. Geoforum 40 (5) 884-894.

Young, O. R. 2008. Institutions and environmental change: the scientific legacy of a decade of IDGEC research. In O. R. Young, L. A. King, and H. Schroeder (eds.) Institutions and environmental change: principal findings, applications, and research frontiers. Cambridge, MA: MIT Press. Pp. 3-45.

Zimmerer, K.S. 2006. Cultural ecology: at the interface with political ecology - the new geographies of environmental conservation and globalization. Progress in Human Geography 30: 63-78. 